\title{
The Nature, Form and Functions of Yoruba Proverbs: A Socio- Pragmatic Perspective
}

\author{
Osoba, Joseph Babasola, Ph.D \\ Department of English University of Lagos Akoka Lagos, Nigeria
}

\begin{abstract}
$A B S T R A C T$
This study explicates the nature, form and functions of Yoruba proverbs from a socio-pragmatic perspective. The sample of Yoruba proverbs used in the study was collected at Ile-Ife in Oranmiyan Local Government Area of Oyo State between the $18^{\text {th }}$ and the $22^{\text {nd }}$ of April, 1985(about 29 years ago). A much recent sample of similar proverbs was collected between February 2010 and March 2012 randomly. Two methods used in the collection are (1) tape recording and (2) anonymous observation and note taking. The socio-pragmatic functions of Yoruba proverbs are discussed under (1) Educational Role and (2) Rhetorical Role and (3) Anecdotal Role. Our choice of Yoruba proverbs is predicated on the following: (1) The way and manner Yoruba people used proverbs in their various occasions and situations make them fascinating and appealing and (2) the manner in which socio-pragmatic functions are conveyed through them. Since much research is still needed as regard this aspect of language use, this paper therefore attempts to provide a new intellectual insight into the sociopragmatic nature, form and functions of Yoruba proverbs used in Ile-Ife, in particular, and other Yoruba towns in general.
\end{abstract}

\section{General Introduction and Background to the Study}

The sample of Yoruba proverbs used in this study was collected at Ile-Ife between 1985 and 2010. The primary material was collected from Ife indigenes, some of whom still live at Ile-Ife today.

\subsection{Geography, Social History and Occupation}

Ile-Ife is a Yoruba Town some 54 kilometres to Ibadan, the former Capital City of Osun State, Nigeria. It is the headquarters of the Oranmiyan Local Government Area and lies between latitude $7^{0} 25^{\circ} \mathrm{N}$ and Longitude $4^{0} 30^{\prime} \mathrm{E}$. It has a fairly rough topography and a fairly constant annual rainfall.

There are different legends concerning the origin of Ile-Ife and consequently the Yoruba people; since Ife was regarded as the cradle of the Yoruba people.One variant of the legends claims that Oduduwa was the founder of Ile-Ife and that he migrated from North East around Mecca and Arabia. When he and his followers got to Ife, they stopped and settled there. Thereafter, they formed a kingdom at Ife. His descendant later dispersed to various parts of Nigeria where they are found today partly due to population expulsion, adventure motive and hostility among themselves. A proverb among Ife people says: 'The youths are wise, the elders are wise; on this basis was Ile-Ife founded'

Legend also has it that when Oduduwa, with some elders, and young men like Ogun ${ }^{1}$ were about to reach Ile-Ife, the way became impenetrable. It was the young Ogun "who possessed the instrument strong and adequate enough for making the way for all the remaining leaders". ${ }^{2}$ Consequently they were able to reach IleIfe and settle there. This was how Ife was founded.

Ife people mainly engage in farming as occupation. Most of them practise subsistence farming and live by it. A few grow both cash crops and food crops. They possess great property in terms of agricultural land. Though they are farmers, a few of them still engage in part-time hunting and praise poetry. These they combine with their farm work. Today, however, most of them are now in and struggling for white collar jobs. They are benevolent people who love and accommodate strangers easily and cheerfully. They love ceremonies, enjoyment and entertainment.

An average Ife elderly man loves and engages in such games as "Ayo, Arin, Ijakadi" 3 and playing draft, others include "BojuBoju (face-covering game), Talubosa, Ekun meran (tiger-catch-goat game) and Tani wa ninu Ogba (who-is-it-in-compound game)?"4 engage by children. Telling moonlight stories and riddles is also part of their hobby.

\footnotetext{
1 The Yoruba God of Iron

2 Ajibola J.O. Owe Yoruba OUP, Ibadan 1971 pg. 51

3 Ayo, Arin are Yoruba games while Ijakadi is sport-wrestling.

${ }^{4}$ They are all forms of sport for children and adolescents.
} 
According to them "Pounded Yam is the real food, Oka (food made from yam/plantain flour) is the medicine, Eckọ (pap) is taken when none is available, guguru (popcorn) is just to keep the mouth occupied". ${ }^{5}$ Although these people take other food like cassava grains, beans, rice, yam flour and plantain flour and pap they enjoy pounded yam with okra soup most. Their favourite drink is palmwine which they take at any time of the day. Few take Ogogoro (distilled wine).

\subsection{An Informer's Profile}

Most of my informants were born and bred at Ile-Ife and well-versed in the art of using proverbs, their store of knowledge of and ability to use them in any occasion or situation seem inexhaustible. They all reference elders and ancestors.

To them, the ability to know, apply and use proverbs succinctly and aptly depends on experience and association with the elder who are regarded as the custodians and the ones only competent enough to use proverbs at will. Thus at the beginning of every proverb constant reference is made to them.

The informers were interviewed personally with the assistance of friends, associates and colleagues who were living at Ile-Ife. The Yoruba and, in particular, Ife people are fond of using proverbs when they have to make speeches. And indeed it is a pleasure to see how their proverbs blend harmoniously with the point they treat thereby driving home the point so vividly that the audience enter very fully into their feelings.

\subsection{Authorship and Originality}

The question of individual authorship and originality arises in the study of the nature and functions of Yoruba Proverbs. The fact that one of the characteristics of a proverb is that it should be accepted by the community as a whole, made the scope for individual initiative dearly limited. Nevertheless, certain amount of variation in form and the great range of varied situations to which proverbs can be applied with greater or lesser aptness and insights give some opportunity for individual contributions. New proverbs are mentioned as being taken by individuals from various outside sources, or arising from individual inventiveness and poetic imagination within the framework of the conventional forms and functions in any given society. ${ }^{6}$ Thus, it becomes clear that though Yoruba proverbs are regarded as communally owned, there is a scope for individual authorship which is however limited.

Another relevant point to note is that in Yoruba land most of the proverbs that are found in one ethnic group are also present in another. The slight difference occurs only in the dialects in which they are expressed. More so, when Yoruba can be seen as one people sharing one ancestor - Oduduwa, one origin as well as similar sociolinguistic/cultural heritage.

\section{The Nature and Form of Yoruba Proverbs}

Proverbs are one of the many kinds of socio-cultural use of language although the sociolinguistic significance of proverbs in Africa is brought about by their close connections with other forms of language use. The Ganda Olugero for instance, means among other things, a saying, a story, a proverb and a parable. ${ }^{7}$

However, in Yoruba language, a distinction does exist in terminology between proverbs and other linguistic forms and expressions. But even here there is often a practical connection between proverbs and other literary forms of language. ${ }^{8}$ Some Yoruba proverbs are connected with stories while other are closely related to anecdote, so much that anecdotes are sometimes just illustration of a proverbs and vice-versa.

\subsection{Definition and Characteristics}

The need to examine some of the definitions and characteristics of Yoruba proverbs arises in this study. The Oxford Advanced Learners Dictionary defines a proverb as "popular short saying with words of advice or warning". Another definition is "a traditional technique of verbal expressions consisting of a compressed statement often in a figurative language and noted for its wit in the selection and arrangement of the verbal item end for the wisdom of its total meaning." The Webster Reference Dictionary of the English Language describes a proverb as "a short, pithy, popular saying long in use, embodying some familiar truth, practical precept or useful thought in expressive and often picturesque language: an adage, a saw, hence a person or thing that has become proverbial, an object of common mention or reference or a by word; a wise saying or precept, pr a didactic sentence". ${ }^{9}$

\footnotetext{
5 A popular saying among Ife people.

${ }^{6}$ Ruta Finnegan. Oral Literature in Africa pages 417 to 418.

${ }^{7}$ Ruth Funegan 1978, page 390

${ }^{8}$ Ruth Funegan 1978, page 391

${ }^{9}$ Appendix 1 no 97
} 
All these are English definitions of a proverb. The Yoruba also have their own definitions of a proverb. And according to them "a proverb is the horse which is used in tracing lost words". The literary quality of this proverb is enhanced by the metaphor "a proverb is the horse". ${ }^{10}$ As a horse is a reliable means of communication: Conveyance to battle fields and long distance. So is proverb is a suitable means of verbal communication.

Most Yoruba proverbs are "Marked by 'shortness, sense and salt'..." 11a these tripartite qualities distinguish proverbs from other verbal arts. The 'shortness', meaning brevity involves from the Yoruba belief that: 'Half a word is spoken to a wise man, when it gets into his 'inside' it becomes whole" which has an English equivalent in 'a word is enough for the wise'. The 'sense' in a proverb is derived from the total meaning. The allusive nature of proverbs gives rise to the need for a sharp perception to understand and grasp their intended message. This is well illustrated in a Yoruba proverb which says "It is proverb by proverb that 'agidigbo's drum is beaten, only the wise can dance to it and only the knowledgeable can understand". ${ }^{2 a}$ The saltiness of Yoruba proverb is enhanced by the elaborate use of figurative language which include: metaphors, similes, personifications, symbols etc. It is in the proverbs that the Yoruba's fondness for imagery, symbols and allusions is most typically realized. As salt is an essential ingredient in a soup in adding sweetness to taste, so is proverbs in the art of speech making, adding poetic flavour to the statements.

\subsection{The Role of the Elders:}

Among the Yoruba, the ability to use proverbs appropriately is an evidence of wisdom and intelligence. This however, is often associated with elders who through their past years have acquired a lot of experience. This may account for the fact that only elders are usually accorded the position of an orator during an important discussion. ${ }^{11}$ One curious aspect is the customary homage that one pays to the Elders in the process of telling a proverb. The norm is to make a little bow and such statements as "It is the Elders who make a proverb that, as the elders say or as the Yoruba say..." before the proverb is delivered. And at the end of the proverb, one may say "Toto', it sounds like a proverb, if I have trespassed, may the elders forgive me." Then the audience will respond, "You will tell another" (proverb) implying that the speaker's foundation of proverbs will never become dry. The importance of this dramatic aspect lies in the fact that it enhances the audience's alertness and participation in the on going address or discussion.

The Yoruba accord great respect to their elders because they are the custodians of their socio-cultural heritage. Their role in Ile-Ife in particular and Yoruba society in general is aptly summarized in the Yoruba proverb that says:

"When there are no elders in town, the town degenerates, when the head of the family dies, the house becomes desolate". ${ }^{12 b}$

Another says:

"An elder cannot be in the market and a child's head will be allowed to droop". ${ }^{2}$

\subsection{Form, Style and Structure}

Proverbs are picked out first and most obviously as being short; and secondly by the fact that even where the wording itself is not absolutely fixed, at least the main structural pattern is accepted in the society concerned as an appropriate one for this purpose. This is particularly true of Yoruba proverbs.

In addition to terseness and relative fixity, most 'Yoruba' sayings classed as proverbs are also marked by some kind of poetic quality in style or sense and are in this way set apart in form, from more straight forward maxims. ${ }^{13}$

In the analysis of the style and structure of Yoruba proverbs, one immediately notices the poetic form in which many of them are expressed. This, in addition to their figurative mode of expression, serves to some degree in setting them apart from everyday speech. Yoruba proverbs however can be conveyed in many other ways such as simile and metaphor.

a. There is the literal forms of Yoruba proverbs which often consist some allusion: or picturesque form of speech.

Examples of this kind are common in Yoruba Proverbs. "A sharp knife does not prepare the handle that is already fixed to it". ${ }^{14}$ Or the "Corn becomes ripe while the farmer is yet living" ${ }^{15}$. These are literal forms and

\footnotetext{
${ }^{10}$ Ruth Finnegan - 1978 pg. 393

11a. Appendix 1 no

${ }^{11}$ a Appendix 1 no 98

12b Appendix 1

${ }_{12}^{12}$ Appendix 1 no 21

${ }^{13}$ Ruth Funnegan 1978, page 395.

${ }^{14}$ Appendix 1 no - 13
} 
they present the thought in a simple, direct and straightforward way". Some others include "A cock develops from an egg". ${ }^{16}$ There is a sort of picturesque form here representing the stages of developing from the early stage to the mature age or stage. This proverb may also be seen as an allusion to the fact that there is an indirect reference to the development of man from the childhood to the adult stage, or those that are marked by some poetic quality such as rhythm. Consider for instance, "if the right hand washes the left and left washes the right, the hands will be cleaned" 17 or another Yoruba proverbs that says "A beautiful woman without manners has nothing but vanity". ${ }^{18}$ General advice is often given in this form as in "friend is friend, market is market, no one gets gratitude fro selling at a cheap rate". ${ }^{19}$ One pertinent point about the literal form of Yoruba proverbs is that, they are relatively explicit and the meaning can be derived from surface level, although they sometimes appear as allusion picturesque form and may conceal deeper meaning.

Another important aspect of Yoruba proverbs is the Figurative form they appear. Here direct similes occur frequently. In fact there are many examples of direct comparism that could be cited in Yoruba proverbs. "A fruitful woman is an arch-enemy of a barren woman, so is a hard-working person to a lazy one " ${ }^{20}$ This proverb is comparing two people. Here the proverbs suggest that a fruitful woman is like a hard-working person while a barren woman is nothing but a lazy one. However, this is to say that the figurative meaning is brought out vividly by direct comparison. Another one goes thus:

"Restless efforts are not criteria for one to be rich, working like a slave does not make one become important". The simile is expressed in working like a slave....." ${ }^{21}$ Another says "He who fails to pay gratitude to those who helped him is like a thief who robs one of our property". 22

\section{c. Metaphorical Form}

However comparison is also evoked metaphorically. In Yoruba proverbs: "A proverb is the horse which is used in tracing lost words". The figurative quality of this proverb is enhanced by the metaphor "A proverb is the horse". Thus "a dish takes soup in its own face" comments on egotism and another "Until Ekiri dies, its skin is never used for gbedu drum" ${ }^{23}$ Generalizations about animal such as 'Ekiri' abound in Yoruba proverbs.

d. Concrete form: Perhaps even more common than the metaphorical generalization is the form in which a general or abstract idea is conveyed not through any direct generalization at all but through a single concrete solution which provides only one simple example (kekere) of the general point. ${ }^{24}$ This is true of Yoruba proverbs "it is in the presence of a kolanut dealer that worms enter his kolanuts",25 and another that says "There is no use for cloth, Omoye has entered the market place naked" ${ }^{26}$ express general idea about man's helplessness or inability to reverse certain things in nature by mentioning specific situations. Thus "he whose head is used to break a coconut doesn't eat it" ${ }^{\text {"27 }}$ well illustrates this.

e. Hyperbolic and exaggerated forms are also frequent often found. Thus "a knotty problem is difficult to solve as three pieces of yam are difficult to tie" 28 and "He who waits to see a crab wink will tarry long upon the shore" ${ }^{29}$ are examples of exaggerated forms of Yoruba proverbs. It should be noted here, however that the forms of Yoruba Proverbs treated in this paper are inexhaustible and the more general ones.

Unlike stories and songs, the performance does not generally seem to be of importance. Rather "Yoruba" proverbs rely for their socio-pragmatic effect on the aptness with which they are used in a particular situation and on the style and form of words in which they are used. ${ }^{30}$

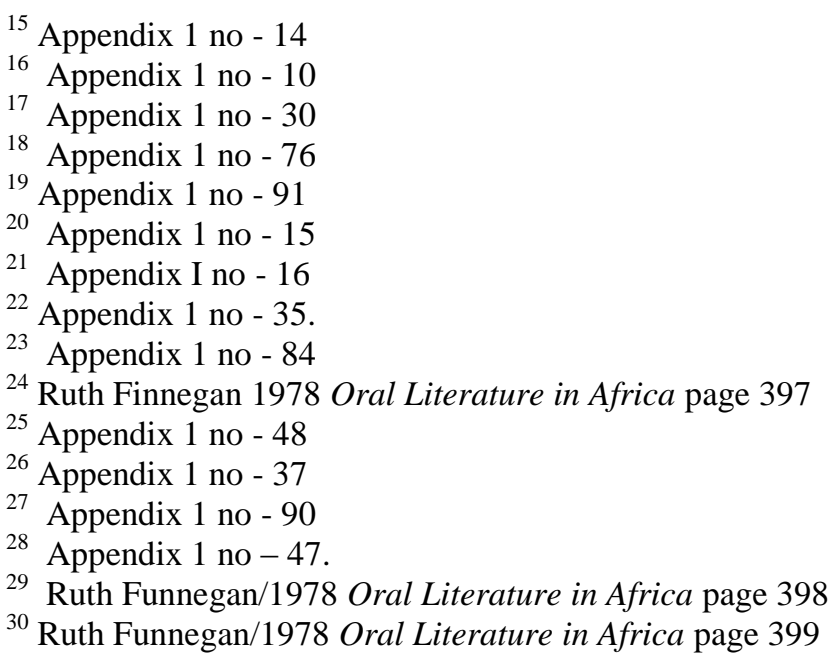


Pithiness and Economy are usually noticeable in the Yoruba proverbs and these are well summed up in their proverb which says "Half a word is spoken to a wise man when it gets into his 'inside' it becomes whole".

There is wide spread evidence of balanced proposition in Yoruba proverbs for instance they may come in couplets with antithesis between the two lines, nouns answering to noun verb to verb: "Adetu" head longs for an "Aran', ${ }^{31}$ the head of Aran seller longs to become a kings." 32 and "worthless persons are more than forest, good persons are dearer than the eye." ${ }^{33}$ and he that is bellyful flattens his stomach while he that is hungry expands his" "34. There is also the use of syllogism which is well explained in "a witch cried yesterda7y, and a child died today, who does not know that it was the witch that kills the child" 35 though the logic of this proverb appears unsound, owing to its sweeping generalization and imperfect grasp of the nature of connection and invalid conclusion, its general use is a reflection of Yoruba's belief about witch craft.

There is also the use of pun and Alliteration in Yoruba Proverbs (Ile-Ife). This is evident in Yoruba proverb that says

'Agbalagba ki ise langbalangba'

'An old man does not make fun of himself'.

Although this stylistic device is altogether lost in translation, pun or alliteration is in the use of 'agbalagba' and 'langbalangba' to drive home the message vividly.

The question of the actual style of proverbs appears to demand further research. However, from the details of Yoruba proverbs it is obvious that some sort of heightened speech, in one form or the other is frequently used. And this makes them distinct from ordinary speech.

\subsection{Content}

Sociolinguistically, the content of Yoruba proverbs can be classified under various categories and headings. Two major headings (although there are many more) have been identified in this study. These are "Educational Role" and "The Rhetorical Role". Under the former, the content of Yoruba proverbs includes beliefs and philosophy, moral, individual and collective roles. And under the latter, the content includes warning and advice, allusions and anecdotes, private ends, settlement of disputes/conflicts and entertainment.

The preliterate Ife society relies on proverbs as one of the means to educate youth on their religions beliefs, philosophy and morality. This is well illustrated in the content of "He who witnesses how Sango (god of thunder) enters the ground will never abuse Oba Koso (the king did not hang himself)." avoid a pointed stick from piercing into one's eyes is to walk away from it, at a distance". ${ }^{37}$ And another says "Manner is the beauty of man" There is moral in "to remove the pot, the kolanut tree is cut, to remove the bead, a child's head is cut". ${ }^{38}$

A good number of Yoruba Proverbs (Ile-Ife), in which the didactic aspect is secondary, serve as Rhetoric and are commonly used to win an argument to establish a fact. There are those with domestic instruments and other elements in its content. Consider "When a log gatherer collects his logs, it is on his head that he carries them" 39 or "As long as there are lice on the head, there will be blood on the tip of fingernail". 40 Thus constant references are made to inanimate objects, like food-yam, water, and keg, needle, log and animates hen, dog and tortoise, "if we don't because of yam take palm oil, let us because of palm-oil eat yam" 41 or "it is water that splits, the keg has not broken"42 and for political end may say "small as the needle is, it is not something the hen could swallow". ${ }^{43}$ Also the content of Yoruba Proverbs, Religion, Moral philosophy, human activity, Anecdotes, advice, animals, or the frequent reminder that even power must bow some times express by "The river carries away an elderly person who does not know his weight" 44 or to show that nobody is indispensable or co-operation or collective roles in "The hand of a child cannot reach the ceiling; the hand of an

${ }^{31}$ Aran a Yoruba tradition cloth
${ }^{32}$ Appendix 1 no - 90
${ }^{33}$ Appendix 1 no - 40
${ }^{34}$ Appendix 1 no - 92
${ }_{35}$ Appendix 1 no - 5
${ }^{36}$ Appendix 1 No 2
${ }^{37}$ Appendix 1 No 17
${ }^{38}$ Appendix 1 No 33
${ }^{39}$ Appendix 1 No 84
${ }_{40}$ Appendix 1 No 85
${ }_{4}^{41}$ Appendix 1 No 66
${ }^{42}$ Appendix 1 No 71
${ }^{43}$ Appendix 1 No 60
${ }_{44}$ Ruth Funnegan 1978 , Oral Literature in Africa pg 405 
adult cannot enter a gourd" 45 or emphasis the role of woman "we are talking about pumpkins. A woman asks, 'what are we talking about we say "This is man's talk'. But when we gather the fruit who will cut them up and cook them?"46 or in "A man sees a snake, a woman kills it what is important is that the snake is killed" importance of money "Money says "I am not at home let no one deliberate in my absence" 48 or concerning animals" The young chicken makes a short fly and we say 'this is meet' he replies 'should I not come to this world at all?: "All are samples of the contents of Yoruba Proverbs used by Ife people.

\subsection{Context, Occasion and Situation}

There are two themes that one encounters particularly in any discussion of the uses and contexts of proverbs. First, there is the sense of detachment and generalization in 'Yoruba' proverbs. And secondly, there is oblique and allusive nature of expression through 'Yoruba' proverbs which makes it possible to use them in a variety of effective ways. ${ }^{49}$ Among Ife people Yoruba proverbs are used to settle internal or external disputes. It is believed that 'a counselor who understands proverbs will soon set matters right' such disputes may be on family or land matters or chieftaincy tussle. If, for instance, a man quarrels with his wife to the extent that the former resolves to send her away: for the sake of the children, the elders will pacify the man with a proverb 'if we don't because of Yam take palm oil, let us because of palm oil eat yam'. And peace will be restored, though it may be temporary, in that family.

A disobedient child in Ife society is likened to "A dog that will be lost will never heed the hunter's whistle". This implies that a child who fails to heed the advice of his elders will be lost. ${ }^{50}$

Ife people have a way of sympathizing with and advising themselves. If a man falls into the hand of thieves and his good are stolen but his life is not tampered with they will say "The death that should kill us, if it removes our caps, we should be grateful" it". .2

The importance attached to morals in Ife society cannot be over-stressed. To them "A beautiful woman without manners has nothing but vanity". ${ }^{33}$ And a well behaved person is called 'Omoluwabi'. This is a compressed word for 'Omo ti Noa bi' which means literally 'the child whom Noah gives birth to'. This a biblical allusion to Noah, a man of God, who was saved with seven members of his family after the great flood that destroyed the world. Youths are therefore warned and admonished to keep good company because "A sheep that walks with dog will eat shit". ${ }^{54}$ And if a persons likes to interfere in other people's affairs he may be cautioned by". He whose head is used to breaks a coconut doesn't eat it".

The context of the Yoruba proverbs for their full understanding depends on occasion and situation. Thus in the analysis of the context we see them interwoven. It is quite impossible to appreciate the proverbs in term of context without discussing the occasion and situation.

\section{Educational Role}

It has already been mentioned earlier in this study that the Yoruba people, especially the Ife society, relies on proverbs as one of the means of preserving their culture and educating their youth on their religious belief, tradition, philosophy and moral. However, before we advance further it is necessary to emphasise that "proverbs rely for their effect on the aptness with which they are used in a particular situation". ${ }^{55}$ The Ife people compared words to eggs as expressed in the proverb which says: "words are eggs, when they strikes the ground, they break". ${ }^{56}$ The literary significance of this proverb lies in the metaphor, 'words are egg'/ eggs are fragile and should be handled with care because once they break they cannot be made whole again. So are words: The pitfalls of careless statements are often escaped through apt usage of proverbs. A belief about "Sango" ${ }^{\text {"57 }}$ is

\footnotetext{
45 Appendix 1 no 24

${ }^{46}$ Appendix 1 No 26

47 Appendix 1 No 27

48 Appendix 1 No 65

49 Ruth Funegan 1978 page 408

50 Appendix 1 No 77

51 Appendix 1 No 72

52 Appendix 1 No 73

${ }^{53}$ Appendix 1 No 30

54 Appendix 1 No 31

55 Funegan Ruth, 1978 Oral Literature in Africa page 399

56 Appendix 1 No. 1

57 'Sango' Yoruba god of Thunder
} 
expressed "He who witnesses how Sango enters the ground will never abuse "Obakoso" ${ }^{\circ 5}$ The purpose of this proverb is to make the society reverence the deities.

The following proverbs are spoken to express the wisdom and the philosophies of the Ife people. "The head band is not elegant unless it is well tied and even if it is well tied, it is not graceful unless it suits the wearer". ${ }^{59}$ This is a thought provoking message for a fop: for it is not enough that one could buy and wear many elegant dresses but that whether they suit the wearer is what matters. "A thoughtless hardworking man is not better than a lazy man". ${ }^{60}$ These two proverbs serve as checks on anyone with a wrong attitude to things and situations. However, the latter comment on the attitude to work that it is more rewarding to combine handwork with common sense.

The Ife people also believe that prevention is better than cure. This is implied in the proverb. "The only way to prevent a pointed stick from piercing into one's eyes, is to walk away from it, at a distance" ${ }^{61}$ This means that one has to avoid trouble when it is far off.The 'eyes' and the 'pointed stick' are used figuratively. The eyes are valuable possession. The pointed stick is an agent of destruction. The beauty of the proverb lies in the fact that it will be an act of foolishness or stupidity to allow an agent of destruction to destroy one's valuable possession because one lacks foresight. This proverb teaches one to be vigilance on anything one does. There is a moral value in the Yoruba proverb which says "One should not go to bed with the roof on fire" 62 and another says "A sheep which walks with a dog will eat shit" or "Manner is the beauty of man". These proverbs are said primarily to inculcate morals. Thus emphasizing the importance this people attach to morals.

Proverbs are also used to educate every member of the society on his individual as well as collective role. The elders have their roles "An elder can not be in the Market and a child's head will be allowed to drop"63 and also the Youth "A child who knows how to wash his hand will eat with the Elders" 64 and both the Elders and the Youth in "The Youth were wise the elders were wise, on this basis was Ile-Ife founded" 65 or in "A man sees a snake, a woman kills it what is important is that the snake is killed." ${ }^{66}$ This proverb show 'women' are expected to co-operate with men in their commitments.

"Keep you mouth shut, the appellation for Ijora's sheep, not all that the eyes see should be reported by the mouth". ${ }^{67}$

This is anecdote and the proverb is the derived from a tale about one Mr. Ijora's sheep. This sheep often told its owner all that was going on in the town but warned him never to leak the secret that it (sheep) could speak like a human being. One day, however, Ijora went to the king and boasted that he had a sheep that could speak like a human being. The king, in disbelief, called Ijora liar and resolved to kill him as a lesson to others if the matter proved false. The sheep was brought before a large crowd in the palace and Ijora was called upon to speak to his sheep for a long time the sheep kept silent despite Ijoraa's pleading with it that its silence might lead to his death.

Eventually, the king ordered that Ijora should be killed for telling a lie. As the king's messengers were tying Ijora`s hands and feet, ready to throw him into a furnace of fire, the sheep exclaimed, to everybody's surprise: "What offence has my owner committed that you want to kill him for". On that note, Ijora was annoyed with his sheep for nearly disappointing him. But the sheep told him: "It is not all that the eyes see that the mouth talk about". This proverb is meant to discourage tale-bearing.

\section{Rhetorical Role}

There are many Yoruba proverbs that mainly serve a pragmatic purpose and are often used to win an argument, establish a fact, settle disputes, express sympathy, caution or warning or entertain. Here, however, the didactic aspect appear (if at all) secondary.

Money is highly valued in Ife society and thus given a praise name, "Owo ape ka nu ko' meaning 'Money which we have to call with a curved mouth'. Actually one has to curve one's mouth in order to pronounce the Yoruba name for money. And thus to establish a fact and show the importance of money, the elders say: poverty`s name is "Who knows you" while money`s name is "I am your relation". ${ }^{68}$ Poverty and

58 Appendix 1 No 2

59 Appendix 1 No 3

60 Appendix 1 No 16

${ }^{61}$ Appendix 1 No 17

62 Appendix 1 No 32

${ }^{63}$ Appendix 1 No 21

${ }^{64}$ Appendix 1 No 22

${ }^{65}$ Appendix 1 No 23

${ }^{66}$ Appendix 1 No 27

67 Appendix 1 No 36

68 Appendix 1 No 63 
money are personified in this proverb. Nobody wishes to befriend poverty, but everybody likes a relationship with money and hence "He who has no money but wants a chieftaincy title, it is 'chief shoe carrier' that he will become". ${ }^{9}$

If a person is fond of suggesting or doing to others what himself cannot tolerate a proverb can be used to caution him thus "Judge yourself with what you suggest to others is what Ife (oracle) says of the owner of one clothe during harmattan, when Ifa priest told him to sacrifice his only cloth; Then the owner of one clothe during harmattan replied 'let what will happen happen, I will accept, but to use my only cloth as sacrifice, I will not". 70

This proverb is also an anecdote and encourages a proper consideration of every advice that one is given. The man with one clothe during harmattan has used his common sense to prevail over the Ifa priest's foolish and wicked suggestion; the latter's importance as the mouth piece of Ifa oracle notwithstanding. To have blindly obeyed the priest would have exposed him to pneumonia or other sickness as a result of cold.

Some of these proverbs also serve as means of entertainment. They produce comic effect on their listeners which does not undermine their message in any way. Thus, "He that is bellyfully flattens his stomach while he that is hungry expands his". ${ }^{71}$ Although there is parallelism in this proverb that is, the people involved are playing the parallel role that befits the other: it is more of an antithesis, since both the ideas and the phrases are strongly contrasted. Another says "There is no deity likes Oesophagus it is everyday that one pays sacrifice to him". ${ }^{72}$ This proverb simply means that one eats everyday. However the literary effect is created by the personification or deification of the Oesophagus and the likening the 'intake' of food as a daily ritual. "The horse is suffering, you say 'it can dance very well.' The iron is pricking its stomach and the rope is biting its tongue" ${ }^{, 73}$ There is irony an element of sarcasm in this proverb in viewing of the horse's situation from a wrong perspective; praising the person that should be pitied.

From the foregoing analysis it is obvious that Ife people's socio-cultural patterns of life are clearly revealed in Yoruba proverbs and that not all the proverbs belong to the past. New proverbs emerge daily in the process of conversation. Hence proverbs are like an art that lives!

Thus, one may rightly assert that "If brevity and elegance are regarded as the two main excellence of a proverb, the Yoruba aphorisms may claim equal rank with those of any other nations in ancient and modern times.",74

\section{Anecdotal Role}

Anecdote is defined as a short, usually amusing, story about some real persons or events. The first proverb says: "Time overlaps and the foolish forgets a past kindness is what Ifa Oracle says of Lagere when he wanted to ascend the throne of his father". ${ }^{75}$

The story goes thus: Lagere was a cripple at the time it was his turn to succeed his late father. But Lagere's physical deformity prevented the king-makers from allowing this heir-apparent to ascend the throne. Lagere became sad and resolved to go and drown himself in a river, a python came out and asked him the reason behind his intended action. The python heard his tale and resolved to help him. The python leapt on Lagere and stretched the latter's body until the lamed legs straightened up.

Lagere became physically alright and went back to the town. Eventually, he has crowned as the king. In gratitude to the python's kindness, Lagere set a period apart to pay sacrifices and worship the mysterious reptile. This was done for many years until one day when Lagere's head was swollen with pride. It dawned on Lagere that it was unbecoming of his royal personality to condescend so low as to worship what to him then became a mere animal. Lagere ordered that the python should be brought to his palace and instead of his making sacrifice to the python, the latter should be sacrificed to him. When the python was brought to the palace; it pleaded for demand and reminded the king of the past kindness. But Lagere was not moved by the python's plea. As it was about to be taken to where he would be killed, it leapt up and struck Lagere. And the crippleness returned to Lagere who was eventually dethroned and left to suffer in humiliation. The python crept back to the bush. Thus the preceeding proverb was derived from the above tale.

The second says: "To remove the pot, the kolanut tree is cut, to remove the head, a child's head is cut". ${ }^{76}$

The story goes: A long time ago, there were two intimate friends. One went to the other's house to borrow a pot to cover a newly planted kolanut tree besides his house so as to prevent it from damage from the sun and

\footnotetext{
69 Appendix 1 No 64

70 Appendix 1 No 69

71 Appendix 1 No 92

72 Appendix 1 No 95

73 Appendix 1 No 94

${ }_{74}$ Ogunbowale, P.O. 1970. The Essential of the Yoruba Language page 125-6.

75 Appendix 1 No 34

76 Appendix 1 No 33
} 
domestic animals. The owner of the pot also borrowed from his friend as a necessity a bead to put on the neck of his young daughter. The kolanut tree grew up and yielded much profit to its owner. The lender of the pot became jealous of his friend's posterity and resolved to demand for his pot. To get the pot, the kolanut tree had to be cut. All efforts to make the pot lender rescind his decision proved abortive. Consequently, the tree was cut. The pot lender's daughter also grew up into a beautiful girl and became the idol of many young men but with the head in her neck. It was at this stage that the bead lender went to his friend to demand for the bead. To remove the bead is impossible without cutting the head of the lady. Pleading were to no avail as the bead lender reminded his friend of the fate that befell his kolanut. Pathetically, the girl's head was cut off. And thus the story became a proverb.

Finally, the pragmatic nature of Yoruba proverbs is further emphasized in the two anecdotic proverbs treated above. The first teaches us not to be an ingrate, the second teaches us to beware of what we sow; for one who sows a wind will reap a whirl wind. The beauty and performance and not only the functions are selfverifying as evidence from the two anecdotic proverbs treated above.

\section{Conclusion}

From our examination and explication of the sample of Yoruba proverbs, certain insights can be deduced. First, it is possible to conclude that proverbs pervade and permeate the socio-cultural lifestyle of Yoruba people. Second, as noted by J.O. Ajibola, in his foreword to Owe Yoruba by Bishop A.B. Akinyele, proverbs can be described as "The poetry and moral science of the Yoruba nation." 77 Third, and finally, it is clear that Yoruba proverbs are not restricted to any linguistic or literary form. They may be in form of prose or poetry. Hence; it is not uncommon to find some of them as remnants of tales or anecdotes.

\section{GLOSSARY}
Agidigbo
-A Yoruba musical instrument in form of a box
Ekiri
-A typical African bush animal common in
Yorubaland. It has a fairly tough skin that is used for Gbedu drum; Duiker.
Gbedu
-Another typical Yoruba musical instrument.

[1]. Ajibola, J.O. Owe Yoruba, OUP: Ibadan 1971.

[2]. Ajilade, F. "Olojo Festival at Ile-Ife, Headlines No. 93 December, 1980.

[3]. Delano, O.I (1996) Owe L` Esin Oro: Yoruba Proverbs - Their Meaning and Usage Ibadan: Oxford University Press

[4]. Finnegan, R (1970) Oral Literature in Africa. OUP

[5]. Moody H.L.B(1968) Literary Appreciation, Longman Group Ltd.

[6]. Ogunbowale, P.O. (1970) The Essentials of the Yoruba Language, University of London Press

1. Education

\section{Appendix I}

\section{Beliefs}

1. Eyin l'ohun, bi o bale a fo

Words are eggs, when they strike the ground they break.

2. Eni Sango ti oju re wole ko ni b’Oba Koso.

He who witnesses how Sango (god of thunder) enters the ground will never abuse Oba Koso (the king did not hang himself)

3. Gele o dun bi K'amowe, ka mo we ko to ko ye ni.

The head-tie is not elegant unless it is well tied and even if it is well tie, it is not graceful unless it suits the wearer.

4. Enikan ki isupo alaye

Nobody marries a woman whose husband is still alive

5. Aje ke lanaa, omo ku lonii, tan ko mo pe aje ana ni o pa omo je.

6. Bi a ba maa lu Osugbo, ka lu nla, nitori kekere egbaaofa nla egbaafa.

If one wants to join Osugbo cult, it is better to join the bigger, since the first rate 'egbaafa' is the same for joining the smaller as well as the bigger cult.

7. Enu Agba ni obi igbo.

It is in the elders' mouth that colanut ripes.

8. Ogbon Ologbon ki ije ki a pe Agba ni were.

Wisdom subscribed by a previous speaker prevents an elderly man from being called a fool.

77 Ajibola J.O. Owe Yoruba OUP, Ibadan 1971 page 51 
9. Esin ki ko ere asarele.

A horse takes a return journey home willingly.

10. Eyin ni ndi Akuko.

A cock develops from an egg.

11. Ika ko d'ogba.

Fingers are not equal.

12. Iku Ogun ni ipa akikanju, Iku odo ni ipa Omuwe.

A brave man perishes in battle atlast, so too, a skilful swimmer often ends his life by drowning in water.

13. Obe ki imu ki o gbo eeku ara re.

A sharp knife does not prepare the handle that is already fixed to it.

14. Oju Oloko ni agbado se Igbo

Corn becomes ripe while the farmer is yet living.

15. Gidigidi ko m'ola, ka sise bi eru ko da nkan.

Restless efforts are not criteria for one to be rich, working like a slave does not make one become important.

16. Alagbara ma mero baba ole.

A thoughtless hardworking man is not better than a lazy man.

17. Igi ganganran ma gun mi l'oju okere la ti nwo.

The only way to avoid a pointed stick from piercing into one's eyes is to walk away from it, at a distance.

18. Ogun agbotele ki paro to bag bon.

A battle previously announced does not kill a wise cripple.

19. Eni to n'oka kan si enikeji, merin y'oku ntoka si.

He who points one finger to his neighbour has the other four fingers pointing back to him.

20. Agbalagba ki se langbalangba.

An old man does not make fun of himself.

21. Agba ki wa l'oja k'ori omo titun wo.

An elder cannot be in the market and a child's head will be allowed to drop.

22. Omo to ba m'owo we a ba agba jeun.

A child who knows how to wash his hand will ea with the elders.

23. Omode gbon Agba gbon l'afi de Ile-Ife.

The youths were wise, the elders were wise on this basis was Ile-Ife founded.

24. Owo omode to to pepe t'agbalagba ko wo akeregbe.

The hand of a child cannot reach the ceiling, the hand of an adult cannot enter a gourd.

25. Bi owo agba ko ba ja gudu, ani ko si oun ti won nje ti ko ntan.

If an adult does not partake in a scuffle over dishes, he will say, "nothing is eating that does not finish".

26. A nsoro elegede, obirin ni k'la nsoro re, ani oro okunrin ni yi, sugbon nigbati a ba ko l'egede d'ele, tani yio ge, ti yoo se?

We are talking about pumpkings. A woman asks 'what are you talking about? We say 'This is man's talk'. But when we gather the fruit who will cut them up and cook them?

27. Okunrin r'ejo, obirin pa, k'ejo sati ku ni.

A man sees a snake, a woman kills it, what is important is that the snake is dead.

28. Otun we otun, osi we osi l'owo eni fi nmo.

If the right hand washes the left and the left washes the right the hands will be clean.

\section{Moral and Philosophy}

29. Iwa l'ewa omo eniyan

Manner is the beauty of man

30. Obinrin to dara ti ko niwa asan l'oni.

A beautiful woman without manners has nothing but vanity.

31. Aguntan to baja rin, a je igbe

A sheep that walks with a dog will eat shit.

32. Akii fi ina s'ori ile sun.

One should not go to bed with the roof on fire.

33. Won be obi gba 'koko, won be 'mo l'ori gb'ade.

To remove the pot, the kolanut tree is cut, to remove the bead, a child's head is cut.

34. Ore pe asiwere gbagbe, Oun lo difa fun Lagere, nigba ti o ma je oye baba re.

"Time lapses and the foolish forgets a past kindness." This is what Ifa says of Lagere when he wanted to ascend the throne of his father. 
35. Eni ta se l'ore ti ko dupe, bi ole k'oni l'eru lo ni.

He who fails to pay gratitude to those who helped him is like a thief who robs us of our property.

36. Panumo, Oruko agutan Ijaroa, gbogbo oun oju ba ri ko l'enu nso.

Keep your mouth shut, the appellation for Ijaroa's sheep, not all that the eyes see should be reported by the mouth.

37. Aso ko ba Omoye, Omoye ti rin ihoho doja.

There is no use for cloth, Omoye has entered the market place naked.

\section{Philosophy}

38. Aki I ba agbonu jija oru.

No one engages in a wrestling contest with a braggart.

39. Bi ebiti ko pa eku, a mu eyi fun eleyin

A trap which does not catch the prey must yield up the bait to the owner.

40. Eniyan l'asan po, oju igbe, eni rere won ju oju lo.

Worthless persons are more than forest, good persons are dearer than the eye.

41. A ki I ti oju ogun wa efon.

One does not start preparing for battle after the war has begun.

42. A ki igbon ju bayii ni ngo o se nkan mi

One is not wiser than, this is how $\mathrm{i}$ am doing my thing.

43. Adaniloro fi abara ko ni.

One who afflicts us gives us experience that makes us wise.

44. Agbato ko jo ti iya, ta ni je se bi ore.

An adopted mother cannot adequately represent one's own mother.

45. Asoro di bi isu meta

A knotty problem is different to solve as three pieces of yam are difficult to tie.

46. Oju olobi ni kokoro se nwo o

It is in the presence of kolanut dealer that worms enter his kolanuts.

47. Ara ki wuwo ki alara ma le gbe.

However, heavy a body may be the owner will move it.

48. Bi gbin fa ikarahun a tele.

When the snail moves the shell must follow it.

49. Oju awo ni awo fi ngba obe.

A dish takes soup in its own face.

50. Ara-ile eni nse eni, melomelo ara adugbo.

Close relations often plan evil agaisnt us, talkless of our neigubour.

2. Proverbs from Tales and Folklores

51. Alo ti awun, abo ti ana re.

The going is that of the tortoise; the return is that of his father-in-law.

52. Obe awun ni ipa awun, eni ti o yo ida, yoo tiu ida subu.

The tortoise's knife is used in killing him, one who draws sword will fall by the sword.

53. Eke otosi ki it oil 'l' owuro.

A poor man's rafter never reaches the ground at down.

54. Oromodiye fo piri, ani, 'eran ree', Oni se ki ma w'aye ni?

The young chicken makes a short fly and we say 'this is meat' he replied 'should i not come to this world at all?

55. A doni l'obirin ko fi oju rere wo ni.

A person who has immoral dealings with one's wife does not look at one with good intention.

56. Abani m'adiye fapa se.

A helper in the process of catching a fowl, had a broken limb.

\section{Proverbs that Emphasis Collective Role}

57. Agbajo owo ni a fi i so aaya.

We use closed fist in tapping our chests.

58. Ajeje owo kan to gbe gba d'ori

A single hand cannot lift up a full calabash to the hand.

59. Ki a rin ki a po, yi yeni nii yeni

4. Proverbs as Rhetoric

To walk in a procession gives dignity.

For private ends:

60. Kikere l'abere kere, ki ise mimi f'adiye.

Small as the needle is, it is not something the hen could swallow. 
61. Eye to ba f'ara w'egun, ehin aro ni yoo sun.

A bird which tries to imitate the vulture will find itself behind the tripod.

62. Aso nla ko ni eniyan nla.

A man is important is not to be measured by his overflowing garment.

63. Osi ni je 'tani mo ori?' Owo ni mje 'mo ba o tan ».

Poverty bears 'who knows you ?' while money bears 'I am your relation'.

64. Eni ti o l'owo to fe joye, akobata ni yoo je.

He who has no money but wants a chiefaincy title, it is 'chief shoe carrier' that he will become.

65. Owo ni bi nko sin le, k'eni k'eni ma daba l'ehin own.

Money says 'if $i$ am not at home let no one deliberate in my absence'.

\section{Settlement of Dispute}

66. Bi a ba tori isu j'epo, o ye ka tori epo j'esu.

If we don't because of yam take palm oil, let us because of palm oil eat yam

67. Aja ti yoo s'onu kii gbo fere ode.

A dog destined to be lost will never hear the hunter's whistle.

68. Eye to info l'oke ti ko mo pe ara ile nwo oun.

The bird that flies in the sky does not know that the people living on the land are seeing its ventral part.

69. Foro ro ara re wo lo difa fun a'la'so kan nigba ooye;

Babalawo s'ope aso kan naa to ni ko wa ti ni ebo.

Alaso kan ni ki Babalawo naa fi oro ro ara re wo; knan ti yoo ba de oun yoo fara mo, amo oun to lke fi aso kansoso na ni ebo.

Judge yourself with what you suggest to others is what Ifa (oracle) says of the owner of one cloth during harmattan, when Ifa priest told him to sacrifice his only cloth, then the owner of one cloth during harmattan repelied 'let what will happen, happen, I will accept, but to use my only cloth as sacrifice, I will not.

\section{Sympathy and Advice}

70. Bi eegun ban le ni k'ama r'oju, boti nre ara aye be lo nre ara orun.

If the masquerade chases one, one should not give up because as human beings can get tied, soc an the heavenly beings.

71. Omi l'o danu, agbe o fo.

It is water that spits, the keg has not broken.

72. Iku ti yoo pani b'o ba si ni, ni fila k'ama d'upe.

The death that should kill us, if it removed our caps, we should be grateful.

73. Ile-Oba t'ojo, ewa l'obu si.

When the palace burns, it is only to add more beauty to it.

74. Agba ti o je ajeiwehin ni yoo ru igbo re d'ele.

An adult who eats all without looking back is doomed to carry home his calabash by himself

75. Agemo ti bi omo re aimojo di own omo alagemo.

A chameleon has given birth to its child, to learn to dance well remains the child's problem.

76. Ore nje ore, Oja nje oja a kii dupe mo ta opo.

Friend is friend, market is market, no one gets gratitude for selling at a cheap rate.

77. Falana gbo tire, t'ara eni l'aagbo.

Falana, face your own, it is one's problem that one should face.

78. Ile ti ko ti oju eni su, okunkun re soro i rin.

It is difficult to walk savely in a place where one does not know when it was dark (in the night).

\section{Warning or Caution}

79. Olaja ni i fi ori gbogbo.

It is he who pacifies a quarrel, that receives the club on the head.

80. Ese giri nile a njofe, ofe tan ese da.

Many legs prompt a prodigal's house for free food, once the free food stops, legs also stop coming.

81. Laiku ekiri a kole fi awo re se gbedu.

Until Ekiri dies, its skin is never used for gbedu drum.

82. Omo raye ko fe ni foro af'ori eni.

Nobody wishes us well, but our heads.

83. Eru ki ba ori ki o sa w'onu.

The head can not be so frightened as to shrink inside.

84. Bi arigisegi ba segi, Ori ara re nil ruu.

When a log gatherer collects his legs, it is on his head that he carries them.

85. Bi ina ko tan l'ori, eje kii tan ni eekanan 
As long as there are lice on the head, there will be blood on the tip of the fingernails.

86. Enu ti igbin fib u orisa ni yoo fi wole 'kuuru.

The mouth that the small uses to abuse the goddess will surely be sued toi craw on the sand.

87. Itakun t'oni k'erin ma jana toun t'erin l'ojo nlo.

A climber stem that attempt to prevent the Elephant from proceeding on his journey is fatted to accompany him.

88. Egan ko ni k'oyin ma dun

Backbiting and jealousy do not prevent honey from being sweet.

89. Ala ti aja la, inu aja nii gbe

The dream dreamt by a dog always lives in its include.

90. Ori Adetu npete aran, Ori elaran npete ati j'oba.

Adetu's head longs for an Aran cloth, the head of aran seller longs to become king.

91. Abiyamo ota agan, eni nsise ota ole.

A fruitful woman is an arch-enemy of a baren woman, so is a hand-working person to a lazy one.

\section{Entertainment}

92. Eni yo npanu, eni ebi npa nrakun

He that is bellyful flattens his stomach while he that is hungry expands his.

93. O so pe oun le d'oju tio, eni ko to be bi oba sope o ko mu'di, eni melo lo ma fi di han lati so pe iro l'onpa.

He says he can spoil your reputation you reply he cannot; if he says you do not wipe your anus, to how many people will you reveal your bottom to prove him false.

94. Iya nj'esin, elo m'ojo, kese ngun ninu, ijanu nje l'ahon.

The horse is suffering, you say 'it knows how to dance', the iron is procking its stomach and the rope is biting its tongue.

95. Orisa bi ona ofun ko si, ojojumo ni gbebo.

There is no diety liek Oesophagus, it is everyday that one pays sacrifice to it.

96. Eniti a fi ori re fo agbon kii je ninu re.

He whose head is used to break a coconut doesn't eat it.

97. Owe l'esin oro, bi oro ba s'onu owe la fi nwa.

A proverb is the horse which is used in tracing lost words.

98. Abo oro la nso fun Omoluabi, bi o ba d'enu re a di odidi.

Half a word is spoken to a wise man when it gets into his 'inside' it becomes whole.

99. L'owel'owe la nlu ilu agidigbo, ologbon ni i jo omoran ni i mo.

It is proverb by proverb that 'agidigbo' drum is beaten, only the wise can dance to it and only the knowledgeable can understand it. 